\title{
THE DESIGN AND BUILDING OF MEDIUM CAPACITY DRYING HOUSE FOR BOKAR
}

\author{
Sri Aulia Novita*,1, Hendra $^{2}$, Perdana Putera ${ }^{2,3}$, Fithra Herdian ${ }^{1}$, Muhammad Makky $^{4}$, \\ Khandra Fahmi ${ }^{4}$
}

\author{
${ }^{1}$ Department of Agricultural Mechanisation Technology, Politeknik Pertanian Negeri Payakumbuh, 50 Kota, \\ Indonesia \\ ${ }^{2}$ Department of Computer Engineering Technology, Politeknik Pertanian Negeri Payakumbuh, 50 Kota, \\ Indonesia \\ ${ }^{3}$ Department of Electrical and Electronics Engineering, University of Nottingham, Nottingham, United \\ Kingdom \\ ${ }^{4}$ Department of Agricultural Technology, Andalas University, Padang, Indonesia \\ *Corresponding author \\ Email: sriaulia@gmail.com
}

\begin{abstract}
Bokar, processed rubber material, is latex obtained from rubber trees of community plantations. The quality of latex can be identified from its features which are white, relatively soft, and odorless. The purpose of this research was to design a simple rubber sheet drying house and examine the quality of dry rubber under Indonesian National Standard. Bokars are processed using a liquid smoke coagulant with a concentration of 10-15\% and it obtained a clean white rubber although it has a slight smoke smell. Before drying, Bokar had ground to gain the thickness of the unsmoked sheet/ USS around 3-5 mm. The components of the drying house include the drying room, heating room, heater, thermometer, blower, plenum chamber, ventilation, drying room door, and electric motor. The capacity of the drying house is $200 \mathrm{~kg}$ of rubber sheet, with a drying temperature of $35-46 o C$ and 6 hours drying time. The rubber produced has good quality with average dry rubber content (DRC) was $73.75 \%$.
\end{abstract}

Keyword: bokar, drying house, dry rubber content

\section{Introduction}

Natural rubber in Indonesia is one of the important plantation commodities taking the role as a source of foreign exchange income, job opportunity, and a trigger for economic growth in new centers in rubber plantation areas. Indonesia is the second largest producer of natural rubber in the world after Thailand. The total export of Indonesian natural rubber in 2014 shared about 2.62 million tones with a value reaching 4.74 billion USD (Ditjenbun, 2015). Indonesian natural rubber export products are mostly in the form of crumb rubber of the SIR 20 quality, which reaches $92 \%$ from the total production. The level of demand and production of rubber has always increased significantly. It is shown by the high demand of companies - rubber products supplying companies in complying of production's need. Based on the results of studies by experts, it shows that the trade prospects of rubber products (Bokar) is very good. 
The process of rubber farming by smallholder produces natural rubber materials such as latex, lumps, unsmoked sheet/USS, crepe and slab. Smallholder rubber is usually processed by using traditional methods. This kind of processing produces low quality rubber, so that the selling price of Bokar received by farmers is relatively very cheap. The process of rubber coagulant usually uses acid ant which produces smelly and dull color rubber. The good quality of Bokar is reflected by the dried rubber content (DRC) and the high level of cleanliness. Effort to improve the quality of Bokar must begin from latex to the final processing stage Solichin \& Anwar (2003). The quality of Bokar must be in accordance with Indonesian National Standard - SNI Bokar No. 06-2047-2002 (Badan Standardisasi Nasional (BSN), 2002), which include the following conditions: it is not added with non-rubber materials, frozen with formic acid / other freezer with proper dosage, stored in a shady place and unsubmerged in water. The quality of this Bokar greatly determines the competitiveness of Indonesian natural rubber in international market.

Bokar material is obtained from Limapuluh Kota regency. This latex will be mixed with liquid smoke coagulant from coconut shell. The use of liquid smoke in processing rubber is proven to be able to produce good quality of rubber in accordance with the requirements of the Indonesian National Standard (SNI) 06-1903-2000 about Standard Indonesian Rubber (SIR) (BSN, 2000). Liquid smoke is commonly used as a latex coagulant and and as odor remover. The results of the research by Tedjaputra et al. (2007) showed that liquid smoke can be applied in rubber processing as a coagulation material (clotting) and as odor control (malodor).

The ability of liquid smoke to agglomerate latex is due to the acetic acid content in liquid smoke. Meanwhile, the control of stink odors by liquid smoke is more due to the content of phenols and other aromatic compounds. The ability of phenol as an anti-microbial can prevent the growth of microorganisms on rubber blankets (Karseno \& Rahayu, 2002).

Bokars that have been made is then ground using a rubber grinder to produce milled rubber with a thickness of 3-5 mm and flat (in accordance with Bokar of Indonesian National Standard). The grinding capacity of this rubber is $37.40 \mathrm{~kg} /$ hour. Its capacity is quite high. The rubber grinding process is carried out to separate most of the water contained in Bokar, so it is easier for the drying process. Then, the milled rubber is dried by being aerated for $\pm 10-14$ days so that Bokar is drier which is called an unsmoked sheet.

To lessen the effort and speed up the drying process of the unsmoked sheet, the rubber drying house was designed. There were two treatments implemented in this study which include the provision of liquid smoke coagulant and the drying process to analyze the effect of drying on the quality of Bokar, especially unsmoked sheet. The equipment used in the drying process is a drying 
house that works automatically. The temperature and the drying time must be controlled so that the expected level of production quality can be achieved.

During the rainy season, $320 \mathrm{~kg}$ of the sheet can be evenly dried to the required $0.5 \%$ moisture content in 5 days. Compared to conventional smokehouses, a better design of the house can greatly reduced fuelwood consumption, from $1.0-1.5 \mathrm{~kg}$ per $\mathrm{kg}$ to $0.3 \mathrm{~kg}$ (Breymayer et al., 1993). A of rubber sheets heat storage with height of $100 \mathrm{~cm}$ has drying time 78 hours with a thermal efficiency of the drying system of $6.71 \%$ (Tekasakul et al., 2017). The drying efficiency of the mixed-mode dryer is $15.4 \%$ higher than the indirect solar dryer $(13.3 \%)$. The moisture content of the rubber sheet decreased from 32.3 to $2.0 \%$ and 29.4 to $8.0 \%$ on a wet basis (Dejchanchaiwong et al., 2016). OrtizRodríguez et al. (2021) have compared two direct and indirect solar drying technologies. The moisture content of the rubber sheet decreased from 45.8 to $0.59 \%$ and from 49.7 to $0.33 \%$ on a dry basis. The temperature of the rubber dryer greenhouse with an additional area panel (PGEP) was $5^{\circ}$ $\mathrm{C}$ hotter than the rubber dryer greenhouse without an additional area panel (PGEP) (Jitjack et al., 2016). Drying the rubber sheet using the Sandwich model greenhouse is $15^{\circ} \mathrm{C}$ and $5{ }^{\circ} \mathrm{C}$ higher than the ambient temperature during the day and night and the rubber sheet moisture content drops from $36.4 \%$ to $2.8 \%$ in less than 2 days (Tanwanichkul et al., 2013). Drying at $50{ }^{\circ} \mathrm{C}$ provides good rubber properties with high PRI values, good mechanical properties, and thermal properties within the normal range (Pianroj et al., 2018).

The design of the drying house should emphasize on the ease of the application. It is also economical and environmentally friendly. Therefore, this research will be carried out by making a simple rubber drying house and providing liquid smoke coagulant to coagulate rubber.

The purpose of this research was to design a simple rubber sheet drying house, to examine the quality of drying rubber in accordance with Bokar of Indonesian National Standard 06-2047-2002 (BSN, 2002), to determine the level of dry rubber produced, to determine the temperature and time constant for drying crumb rubber in order to obtain quality of rubber SIR 20, and to examine the odor of drying rubber produced.

\section{Methods}

The equipment used in this study were workshop equipment, heaters, furnaces and laboratory analysis equipment, while the materials were building materials of drying house, Bokar, liquid smoke and etc. The design of the rubber drying house can be seen in Figure 1.

\subsection{Functional Approach}

Tool design or drying house has parts that function as:

1. Drying Room is a dry rubber area 
2. Blower functions to drain dry air

3. The heater serves to heat the drying chamber

4. Plenum Chamber is a place to distribute hot air

5. Burning Furnace functions to produce hot air by burning bricks with liquefied petroleum gas (LPG)

6. The thermometer measures the temperature in the drying chamber

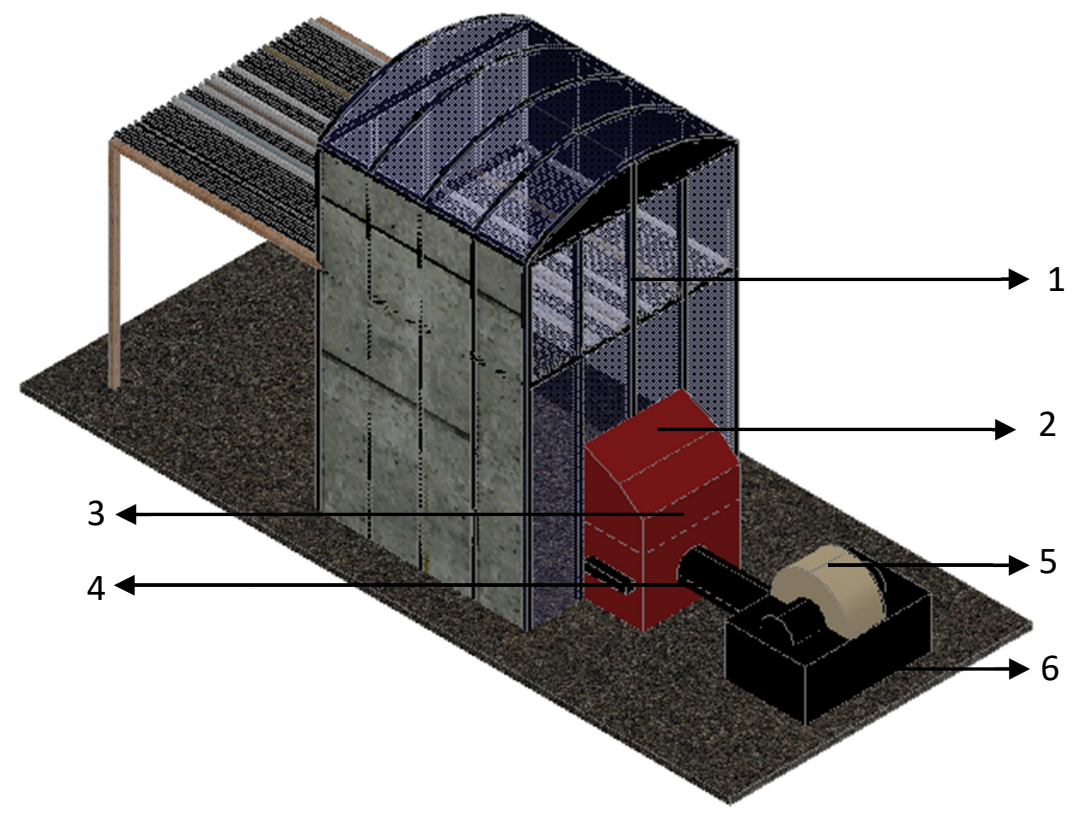

Figure 1. Design of drying house

\subsection{The Process of Making Liquid Smoke and Bokar}

Liquid smoke is made from coconut shells through a pyrolysis process using high temperatures. The formed liquid smoke will be left alone for one week to be separated from the tar, so that it can be used as a natural latex coagulant. The latex will be given liquid smoke around $10-15 \mathrm{ml} / \mathrm{kg}$ of material. Giving liquid smoke is expected to eliminate the smell of latex. After the latex coagulates, Bokar will be milled with a rubber grinder to reduce the high water content, so it eases the process of drying rubber sheet.

\subsection{The Process of Drying of Bokar}

Bokar (unsmoked sheet) that has been given a liquid smoke coagulant will be dried in the drying chamber. Iin this drying process the temperature of the drying air, the drying time, the dry rubber content, the level of cleanliness and the quality of rubber sheet will be determined.

Determination of Dry Rubber Content of Unsmoked Sheet

Determination of dry rubber content

$K=W / W t \times 100 \%$ 
Note: $\mathrm{K}$ is the dry rubber content; $\mathrm{Wt}$ is the weight of latex; $\mathrm{W}$ is the weight of the crepe from the clumping of latex.

$$
\text { Average } \mathrm{K}=(\mathrm{K} 1+\mathrm{K} 2+\ldots \ldots+\mathrm{Kn}) / \mathrm{n} \text { with } \mathrm{K} 1 \ldots . \mathrm{Kn}=\text { dry rubber content for each sample }
$$

\section{Result and Discussion}

\subsection{Bokar (Community Processed Rubber Material)}

Bokar is latex obtained from rubber trees (Indonesian National Standard of Bokar 06-20472002) (BSN, 2002). The rubber processed material can be formed into various kinds of rubber products such as unsmoked sheet, slab and lump. Good quality of latex is the main requirement to produce good Bokar. To get high quality of Bokar, a clean work environment is the most important requirement that must be considered including the cleanliness of equipment used during working and the possibility of latex contamination by any dirt. To prevent the acceleration of latex clumping, the following ways should be considered: equipment for tapping and transportating must always be clean and stainless, the latex must be transfered smoothly to the processing area without frequent shakes, latex should not be exposed to direct sunlight, it can use anti-coagulants such as ammonia (NH3) or sodium sulfite (Na2SO3) (Budiman, 2012).

Deliberate coagulation which is commonly done today is by adding the acids such as formic and acetic acids to reduce the $\mathrm{pH}$ of the latex. Meanwhile, latex can coagulate naturally due to the formation of acidic compounds as a result of overhauling the carbohydrates and lipids contained in latex by microorganisms.

To make unsmoked sheet, the raw material used in this research is fresh latex which has not been added with coagulant material which is obtained from several areas in Limapuluh Kota regency. The latex must be free from any dirt such as; crumbs, leaves and other debris. Then, latex is filtered and put into a rectangular container, and mixed with $10 \mathrm{ml}$ of liquid smoke, stirred and left alone for \pm 4 hours, so that the latex will agglomerated.

After that, the processed latex material will be washed to clean the dirt and then grinding the rubber to reduce water content material to ease the drying process. Liquid smoke grade 3 contains acid, carbon and phenol which can be used as a natural latex coagulant.

The acetic acid in liquid smoke can be used as a coagulation for latex (Solichin \& Anwar, 2003), while the phenolic compounds are proven as anti-bacterial, anti-oxidant and anti-fungal (Novita, 2011). The addition of liquid smoke can prevent fungal growth and smelly odor in Bokar 
which has the impact like the rubber smoking process. Proper treatment in rubber processing will produce high-quality rubber, so that the price of smallholder rubber farming can be increased. Liquid latex is added with liquid smoke at a concentration around $10-15 \%$. The process of latex with liquid smoke coagulants can be seen in Figure 2.

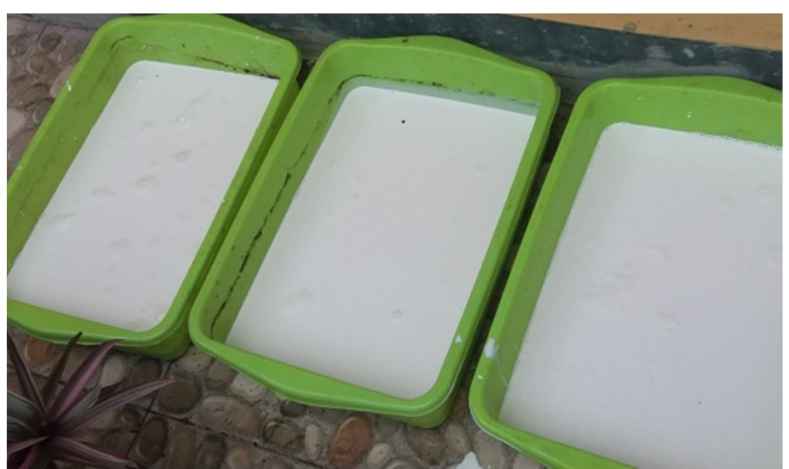

Figure 2. Garden Latex Added liquid smoke

Bokar is left for several hours, until the latex is completely coagulated. The white color showed that it has very good quality as seen in Figure 3. After this process, reducing the amount of air content was done in the grinder.

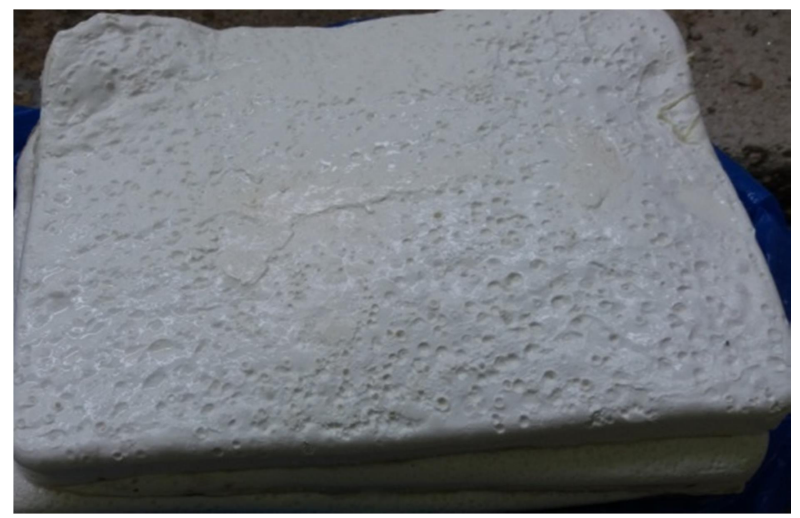

Figure 3. Coagulated latex

\subsection{Rubber Grinding Process}

Bokar will be ground to reduce the water content in Bokar. This rubber grinding process uses a rubber grinding tool that uses three rollers to flatten Bokar. The grinding process must be done after 4-5 hours of coagulation of the latex. If the time is too long, the rubber becomes harder so that it will be difficult to be ground. In the grinding process, the grinding is carried out 4-5 times to get a grinding thickness about 3-5 $\mathrm{mm}$. The thickness of the unsmoked sheet that is obtained is in accordance with the Indonesian National Standard of Bokar. From the performance of the experiment of Bokar, it was found that the average working capacity of the tool was 37.40 $\mathrm{kg} /$ hour. 
With the rubber grinding, it will ease subsequent drying rubber process, because the water content in the rubber has been reduced. If the grinding is uneven, the cooking process will decrease the value of the accelerated storage hardening test (ASHT) after the drying process is carried out. The process of grinding Bokar can be seen in Figure 4.

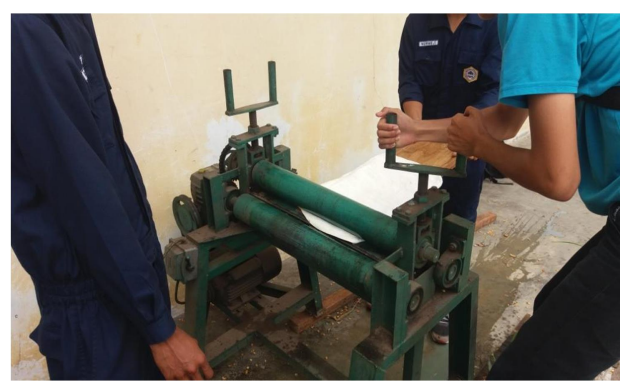

Figure 4. Rubber grinding process

\subsection{The Manufacture of Drying House}

The drying house is a building designed for the drying process of the unsmoked sheet. This drying house consists of a drying chamber (Figure 6), drying shelf, ventilation, roof of the drying house, heater, plenum chamber, blower, combustion chamber (Figure 5), bricks and liquid petroleum gas (LPG).

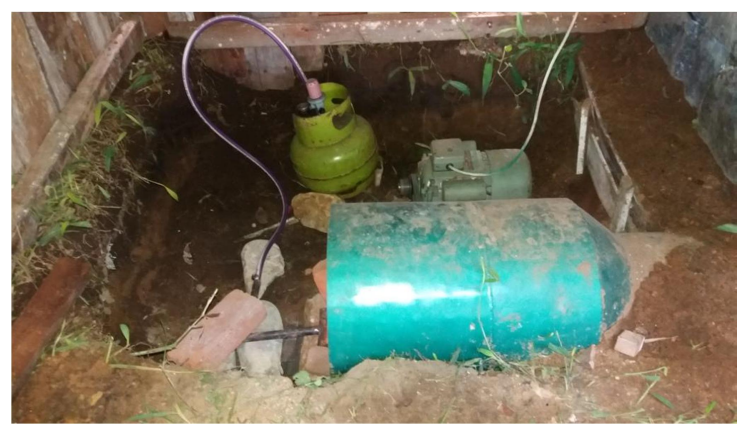

Figure 5. Burning room

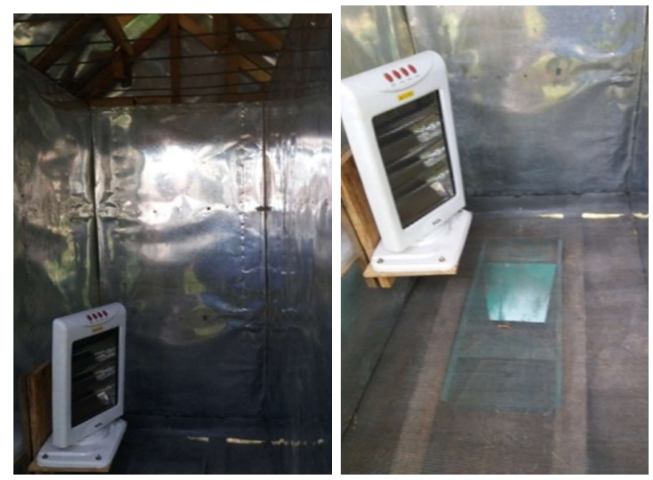

Figure 6. Drying room

The drying house space is allocated mostly to the heating room as an area to produce hot air by burning the bricks with liquid petroleum gas to dry the unsmoked rubber sheet and the 
drying chamber as an area where the ground rubber is dried by stringing it. Other main components of the house consist of the heater, blower, plenum chamber and ventilation. These components have function to convert electrical to heat energy to produce hot air and distribute the hot air.

The drying house can dry Bokar or unsmoked sheet well, so that the quality of Bokar can meet the Indonesian National Standard of Bokar. With proper drying, it will facilitate the rubber storage process for a long time.

\subsection{The Performance of Drying House Bokar}

In order to produce high quality pocessed rubber material that is based on the standard of crumb rubber, SIR 20, proper treatment during the process is required. One of the crumb rubber processing processes that determines the quality of a rubber product is the drying process which aims to maintain the ASHT value of the processed rubber product. Although the ASHT value for SIR 20 is not attached in the Standard Indonesian Rubber (SIR), it is very important to maintain the quality of the crumb rubber produced.

In the SIR 20 crumb rubber process, there are other factors that influence including the type of raw material, the grinding process, and the age of raw material. Considering how important the drying process is to reduce the ASHT value, it is necessary to handle it properly. Therefore, temperature and drying time must be maintained so that the expected level of production quality, which is Standard Indonesian Rubber (SIR) 20, can be met.

\section{Table 1. Data dry rubber content}

\begin{tabular}{ccccc}
\hline No & $\begin{array}{c}\text { Initial weight } \\
(\mathrm{Kg})\end{array}$ & $\begin{array}{c}\text { After drying weight } \\
(\mathrm{Kg})\end{array}$ & $\begin{array}{c}\text { Water content } \\
(\mathrm{Kg})\end{array}$ & Drying content (\%) \\
\hline 1 & 1.3 & 0.98 & 0.32 & 75.38 \\
2 & 1.3 & 0.95 & 0.35 & 73.07 \\
3 & 1.1 & 0.8 & 0.3 & 72.73 \\
4 & 1.1 & 0.79 & 0.31 & 71.82 \\
5 & 0.9 & 0.66 & 0.24 & 73.33 \\
6 & 0.9 & 0.65 & 0.25 & 72.22 \\
7 & 0.75 & 0.55 & 0.2 & 73.33 \\
8 & 0.75 & 0.56 & 0.19 & 74.67 \\
9 & 0.55 & 0.42 & 0.13 & 76.36 \\
10 & 0.55 & 0.41 & 0.14 & 74.54 \\
\multicolumn{4}{c}{ Average of rubber drying content } \\
\hline
\end{tabular}

Based on the discussion above, it is clear that the temperature and drying time need to be kept constant, because this affects the quality level of rubber production. Data from the 
performance of the rubber grinding house to determine the dry rubber content can be seen in Table 1.

The thickness of the unsmoked sheet of Bokar is in the range of $3-5 \mathrm{~mm}$, in accordance with the thickness of unsmoked sheet of Indonesian National Standard of Bokar. The average of dry rubber content obtained from the research data is $73.75 \%$. It shows that the processed rubber has good quality, so that the rubber farmers can increase the price of rubber.

The high amount of dry rubber content that was hanged was due to the low water content of the rubber sheet which was caused by the evaporation process during hanging. In the coagulation of rubber sheet, besides rubber particles, it also contains other materials such as water (Jayanthy \& Sankaranarayanan, 2005). Dry rubber content is the percentage of natural rubber (poliisoprena) particles contained in Bokar, which is rubber sheet. Dry rubber content is a common term used in the natural rubber processing industry (Kumar et al., 2007).

The advantage of having a high dry rubber content on blankets is that the drying process can be done faster because there is less amount of water that has to be evaporated. Drying is an important process to reduce the water content of materials and to ensure the consistency of product quality ( $\mathrm{Ng}$ et al., 2015) This fast drying process will increase the efficiency of production costs. Tham et al. (2014) and Ekphon et al. (2013) stated that the drying process requires a large amount of energy in the natural rubber industry. The lower water content, the shorter the drying time, so that the energy required is lower or more efficient.

The drying temperature using a heat source from gas bricks is in the range of $35-46{ }^{0} \mathrm{C}$ for 6 hours, and temperature control is done by adjusting the gas output in the $3 \mathrm{~kg}$ liquid petroleum gas (LPG). Temperature measurement is carried out by using a thermometer. High drying temperatures can increase or decrease the ASHT value of the rubber depending on the drying time.

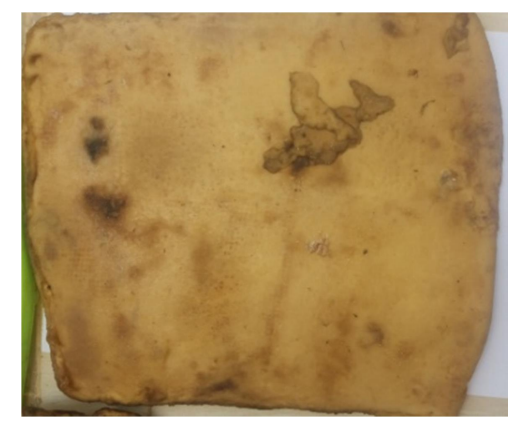

Figure 7. Dried Ribbed Smoked Sit 
The duration of the drying process in the drying room is influenced by the sheet internal factors such as the thickness of the sheet layer (Figure 7), pattern form and softness of the sheet layer. Whilst the external factor are the hanging treatment, way and the tightness of the hanging, airflow control, heat setting, insulation of drying room, fuel type and weather condition.

The result of the unsmoked sheet obtained from drying by using a drying house shows a very good quality. This can be seen from the good color of the unsmoked sheet. It does not have a lot of dirt and odorless or slightly smelly due to the addition of liquid smoke coagulants.

\section{Conclusion}

Based on the report data above, it can be concluded processing of Bokars is in accordance with Indonesian National Standard of Bokar. To produce high-quality Bokar, a natural coagulant which is liquid smoke is used so Bokar is cleaner, odorless and has good quality. Latex will coagulate for 4 - 10 hours after filtration. Bokar which has agglomerated is then being ground using a rubber grinder so that it is called rubber milled (unsmoked sheet), which has a thickness of $3-5 \mathrm{~mm}$. The unsmoked sheet/ USS will be dried in the drying house with two heaters, namely bricks and gas heater and a heater. The drying process using bricks and gas with the drying temperature of $35-46^{\circ} \mathrm{C}$, and with a drying time of 6 hours resulting in dry rubber content as much as $73.75 \%$, to produce unsmoked sheets of good quality. It does not have a lot of dirt and odorless or slightly smelly due to the addition of liquid smoke coagulants.

\section{Acknowledgement}

We would like to thank the Ministry of Research, Technology and Higher Education and Centre of Research and Community Development Payakumbuh State Agricultural Polytechnic who have been willing to fund this research.

\section{References}

Breymayer, M., Pass, T., Mühlbauer, W., Amir, E. J., \& Mulato, S. (1993). Solar-assisted smokehouse for the drying of natural rubber on small-scale Indonesian farms. Renewable Energy, 3(8), 831-839. https://doi.org/10.1016/0960-1481(93)90039-J

BSN (Badan Standardisasi Nasional). (2000). Standar Nasional Indonesia SNI 06-1903-2000: Standart Indonesian Rubber. Jakarta (Indonesia): BSN.

BSN. (2002). Bahan Olahan Karet. SNI 06-2047-2002. Jakarta, Indonesia: BSN.

Budiman, H. S. P. (2012). Budidaya Karet Unggul. Yogyakarta, Indonesia: Pustaka Baru Press. 185-191. 
Dejchanchaiwong, R., Arkasuwan, A., Kumar, A., \& Tekasakul, P. (2016). Mathematical modeling and performance investigation of mixed-mode and indirect solar dryers for natural rubber sheet drying. Energy for Sustainable Development, 34, 44-53. https://doi.org/10.1016/j.esd.2016.07.003

Ditjenbun. (2015). Statistik perkebunan Indonesia 2014-2016. Jakarta, Indonesia: Kementerian Pertanian.

Ekphon, A., Ninchuewong, T., Tirawanichakul, S., \& Tirawanichakul, Y. (2013). Drying Model, Shrinkage and Energy Consumption Evaluation of Airdried Sheet Rubber Drying System for Small Enterprise. Advanced Materials Research, 622-623, 1135-1139. https://doi.org/10.4028/www.scientific.net/AMR.622-623.1135

Jayanthy, T., \& Sankaranarayanan, P. E. (2005). Measurement of Dry Rubber Content in Latex Using Microwave Technique. Measurement Science Review, 5(3), 50-54.

Jitjack, K., Thepa, S., Sudaprasert, K., \& Namprakai, P. (2016). Improvement of a rubber drying greenhouse with a parabolic cover and enhanced panels. Energy and Buildings, 124, 178193. https://doi.org/10.1016/j.enbuild.2016.04.030

Karseno, Darmadji, P. \& Rahayu, K. (2001). Daya Hambat Asap Cair Kayu Karet terhadap Bakteri Pengkontaminan Lateks dan Ribbed Smoke Sheet. Agritech, 21(1), 10-15.

Kumar, R. R., Hussain, S. N., \& Philip, J. (2007). Measurement of Dry Rubber Content of Natural Rubber Latex with A Capacitive Transducer. Journal of Rubber Research, 10(1), $17-25$.

Ng, M. X., Tham, T. C., Ong, S. P., \& Law, C. L. (2015). Drying Kinetics of Technical Specified Rubber. Information Processing in Agriculture, 2(1), 64-71. https://doi.org/10.1016/j.inpa.2015.05.001

Novita, S. A. (2011). Kinerja dan Analisis Alat Penghasil Asap Cair Dengan Bahan Baku Limbah Pertanian. Jurnal Pascasarjana Universitas Andalas.

Ortiz-Rodríguez, N. M., Marín-Camacho, J. F., González, A. L., \& García-Valladares, O. (2021). Drying kinetics of natural rubber sheets under two solar thermal drying systems. Renewable Energy, 165, 438-454. https://doi.org/10.1016/j.renene.2020.11.035

Pianroj, Y., Werapun, W., Inthapan, J., Jumrat, S., \& Karrila, S. (2018). Mathematical modeling of drying kinetics and property investigation of natural crepe rubber sheets dried with infrared radiation and hot air. Drying Technology, 36(12), 1436-1445. https://doi.org/10.1080/07373937.2017.1407939

Solichin, M., \& Anwar, A. (2003). Pengaruh penggumpalan lateks, perendaman dan penyemprotan bokar dengan asap cair terhadap bau bokar, sifat teknis, dan sifat fisik vulkanisat. Jurnal Penelitian Karet, 21, 45-61.

Tanwanichkul, B., Thepa, S., \& Rordprapat, W. (2013). Thermal modeling of the forced convection Sandwich Greenhouse drying system for rubber sheets. Energy Conversion and Management, 74, 511-523. https://doi.org/10.1016/j.enconman.2013.06.020

Tedjaputra, N., Solichin, M., \& Anwar, A. (2007). Penggunaan asap cair Deorub dalam pengolahan RSS. Jurnal Penelitian Karet, 25(1), 83-94.

Tekasakul, P., Kumar, A., Yuenyao, C., Kirirat, P., \& Prateepchaikul, G. (2017). Assessment of sensible heat storage and fuel utilization efficiency enhancement in rubber sheet drying. Journal of Energy Storage, 10, 67-74. https://doi.org/10.1016/j.est.2017.01.002

Tham, T. C., Hii, C. L., Ong, S. P., Chin, N. L., Abdullah, L. C., \& Law, C. L. (2014). Technical review on crumb rubber drying process and the potential of advanced drying technique. 
Agriculture and Agricultural Science Procedia, 2, 26-32, https://doi.org/10.1016/j.aaspro.2014.11.005 